\title{
Venule Endothelium
}

National Cancer Institute

\section{Source}

National Cancer Institute. Venule Endothelium. NCI Thesaurus. Code C49319.

The layer of cells that line the lumen of a venule. 